\title{
Association of Vitamin D Status with COVID-19 Infection and Mortality in the Asia Pacific region: A Cross-Sectional Study
}

\author{
Dharmveer Yadav ${ }^{1}$ (D) Amandeep Birdi ${ }^{1} \cdot$ Sojit Tomo $^{1} \cdot$ Jaykaran Charan $^{2} \cdot$ \\ Pankaj Bhardwaj $^{3} \cdot$ Praveen Sharma $^{1}$
}

Received: 14 October 2020/Accepted: 11 December 2020/Published online: 3 February 2021

(C) The Author(s) 2021

\begin{abstract}
COVID-19 has been declared a global pandemic by WHO on 11 March 2020. Still, very little is known about the potential protective dietary factors for the prevention of infection and mortality due to COVID-19. Keeping in view the scarcity of literature/studies available, in this regards present study was undertaken to assess if there is any correlation between mean levels of Vitamin D in various Asia Pacific countries with the infection and mortality caused by COVID-19. We collected data for mean levels of Vitamin D for 37 Asia Pacific countries for which we have also got the data regarding the morbidity and mortality of COVID-19. The mean levels of Vitamin D were found to have a significant association with the number of cases/million( $\mathrm{r}=-0.394, p$ value $=0.016$ ) and a weak association with the number of deaths/ million $(\mathrm{r}=-0.280, p$ value $=0.093)$ due to COVID-19. In conclusion, we found a significant relationship between Vitamin D levels with the number of COVID-19 cases. So further clinical trial/study with a large sample size is needed to elucidate the protective role of Vitamin D in COVID-19.
\end{abstract}

Keywords COVID-19 - Vitamin D levels · ACE-2 - Asia pacific region

Dharmveer Yadav

dharam143s@gmail.com

1 Department of Biochemistry, All India Institute of Medical Sciences, Jodhpur, Rajasthan, India

2 Department of Pharmacology, All India Institute of Medical Sciences, Jodhpur, Rajasthan, India

3 Department of Community and Family Medicine, All India Institute of Medical Sciences, Jodhpur, Rajasthan, India

\section{Introduction}

Vitamin D, a fat-soluble vitamin, regulates the absorption of calcium, phosphorous, and magnesium. Vitamin D also is known to play a vital role in increasing immunity against individual viral organisms and hence reducing mortality due to infection [1]. It helps in improving both natural and adaptive immunity [2]. Disruption of gap junction has been one of the mechanisms employed by viruses to gain entry into the target cell. Vitamin D prevents viral entry into the cell by maintain integrin proteins and helping in maintaining tight gap junctions [3-6].

Vitamin D is synthesized in the skin on exposure to sunlight. Seven hydroxycholesterol is converted to secosterol which subsequently gets converted to cholecalciferol. Cholecalciferol enters the liver and gets converted to 25 hydroxycholecalciferol. 25 hydroxycholecalceferol transported to the kidney, where it gets converted to the active form of vitamin D calcitriol [7]. Vitamin D enters the cell by binding to its receptor vitamin $\mathrm{D}$ receptor (VDR) and brings about its regulation of transcriptional activity of different target genes by binding to vitamin $\mathrm{D}$ response elements on DNA [7]. Vitamin D plays a role in innate immunity by producing peptides like cathelicidin and interleukin (IL) 37, which acts as an antimicrobial agent [8, 9]. Cathelicidins show its direct killing effect on enveloped and non-enveloped viruses as well as on some bacteria and fungi [10]. These peptides disturb cell membranes and neutralize endotoxins, leading to efficient clearance of invading pathogens [11]. Further, an animal study has shown that a decrease in IL-37 leads to increased replication of influenza A viruses [11].

Amidst the current scenario of the Covid- 19 pandemic, studies are being conducted to elucidate the role of vitamin $\mathrm{D}$ in the prevention of SARS- COV 2 virus infection. The 
entry of this virus into the cell requires angiotensin-converting enzyme 2 (ACE-2). This virus binds to the receptor and gains entry into the cell, and as it attaches to the receptor, it leads to a decrease in the expression of ACE 2. ACE2 receptors are present in epithelial cells of the lungs, blood vessels, intestine, kidney, and heart. ACE 2 functions by degrading angiotensin I to angiotensin I-IX and angiotensin 2 to angiotensin I-VII. Angiotensin I-IX binds to the Mas receptor and demonstrates anti-inflammatory and antioxidant and vasodilatory effects. It is stated that the binding of the SARS-COV 2 virus to the ACE receptor leads to a decrease in the anti-inflammatory response of ACE 2 and leads to the recruitment of inflammatory cytokines and leads to cytokine storm [12, 13].

The current study aimed to assess the correlation between Country-wise average Vitamin D levels and COVID-19 cases and mortality in countries in the Asia Pacific region. The study would provide insight into the protective role of Vitamin D in the infectivity and mortality of COVID-19.

\section{Methods}

We performed an inclusive search of the literature for studies on vitamin D levels and COVID-19 from September 2000 up to 15th September 2020. All observational studies reporting the vitamin D levels from the Asia Pacific countries were searched using a different combination of MeSH terms related to the COVID-19 and vitamin D in Asia pacific countries through PubMed and google scholar. Asia Pacific countries were defined as per the Asia Pacific Observatory on Health Systems and Policies, WHO Regional Office for South-East Asia. Furthermore, references in the relevant articles were also searched to check for other eligible articles. Recent studies depicting average Vitamin D levels for countries in the Asia Pacific region were included for Vitamin D levels. Vitamin D levels mentioned in different units were standardized to $\mathrm{ng} / \mathrm{mL}$. Data for Vitamin D levels were obtained for 37 countries which were included in the analysis (Table 1) for few countries no data was available hence they were excluded. Articles were searched and reviewed for eligibility using the following inclusion criteria 1) mean Vitamin D levels in Asia pacific countries; 2) studies published in English.

\section{Statistical Analysis}

Descriptive statistics were reported in the form of frequency, percentages, mean and standard deviation. As the data was not following the normal distribution, Spearman's correlation was used to evaluate the relationship between the number of cases per million of populations and deaths per million of the population due to COVID-19 with vitamin D level. Statistical analysis was done with the help of Statistical Package for Social Science (SPSS) version 21.

\section{Results}

Total cases per million and deaths per million for each country and the corresponding mean vitamin D levels have been collated (Table 1). Maximum cases per million and death per million were reported in Qatar and Iran respectively while minimum cases per million and death per million were reported from Vietnam and Taiwan respectively. The highest and lowest concentration of vitamin D was reported from Taiwan and Bahrain respectively.

Negative moderate and statistically significant correlation was observed between cases per million and vitamin $\mathrm{D}$ level $(\mathrm{r}=-0.394, p=0.016)$ [Fig. 1]. Mild negative correlation was observed for death per million and vitamin D level $(r=-0.280)$ but this was not statistically significant ( $p=0.093)$ [Fig. 2].

\section{Discussion}

In this study, we did the correlative investigation of vitamin D and its effect on mortality of COVID-19 cases in the Asia pacific population. We performed a correlation between Vitamin D levels and the number of cases and deaths per million till 15th September 2020. Vitamin D levels inversely correlated with the number of COVID-19 cases $(r=-0.394, p$ value $=0.016)$. The highest concentration of vitamin $\mathrm{D}$ as well as the lowest number of deaths per million were reported from Taiwan.Vitamin D regulates the immune system and helps in decreasing the severity of viral infection, mainly related to respiratory systems [14-16]. The active form of Vitamin D 1,25-dihydroxyvitamin $\mathrm{D}$, on binding to vitamin $\mathrm{D}$ receptor (VDR), gets translocated into the cell nucleus and attaches with retinoid $\mathrm{X}$ receptor (RXR). The RXR-VDR complex binds to Vitamin D Response Elements (VDRE) located in the promoter regions of genes affecting the expression of various genes [17].

Covid 19 causes acute respiratory tract infections, and these infections are more prone in individuals with lower vitamin D levels. Various mechanisms had been postulated to explain the role of Vitamin D in the COVID19 pandemic. Vitamin D is known to modulate RAS activity and angiotensin-converting enzyme-2 (ACE2) expression [18]. SARS-CoV-2, on infecting a host cell, would lead to downregulation of ACE2 expression [19]. ACE2 downregulation is accompanied by exacerbated inflammatory 
Table 1 Vitamin D levels, COVID-19 cases and COVID19 deaths per million in Asia Pacific countries

\begin{tabular}{|c|c|c|c|c|}
\hline Sr. No & Country & Cases per million & Deaths per million & Vit D levels $\mathrm{nmol} / \mathrm{L}$ \\
\hline 1 & India & 3565 & 58 & 24.3 \\
\hline 2 & Iran & 4805 & 277 & 61.3 \\
\hline 3 & Bangladesh & 2056 & 29 & 54.2 \\
\hline 4 & Saudi Arabia & 9342 & 123 & 26.9 \\
\hline 5 & Pakistan & 1364 & 29 & 47.0 \\
\hline 6 & Turkey & 3465 & 84 & 42.3 \\
\hline 7 & Iraq & 7289 & 200 & 69.0 \\
\hline 8 & Philippines & 2452 & 42 & 37.8 \\
\hline 9 & Indonesia & 821 & 33 & 59.1 \\
\hline 10 & Israel & 17,643 & 124 & 57.2 \\
\hline 11 & Qatar & 43,441 & 74 & 45.3 \\
\hline 12 & Kazakhstan & 5680 & 87 & 27.0 \\
\hline 13 & Kuwait & 22,289 & 131 & 34.5 \\
\hline 14 & Oman & 17,579 & 154 & 36.8 \\
\hline 15 & China & 59 & 3 & 48.5 \\
\hline 16 & UAE & 8096 & 40 & 52.3 \\
\hline 17 & Japan & 599 & 11 & 36.5 \\
\hline 18 & Singapore & 9811 & 5 & 38.0 \\
\hline 19 & Bahrain & 35,589 & 124 & 22.9 \\
\hline 20 & Nepal & 1892 & 12 & 47.4 \\
\hline 21 & Afghanistan & 993 & 36 & 55.0 \\
\hline 22 & Palestine & 6119 & 44 & 27.8 \\
\hline 23 & S. Korea & 437 & 7 & 43.0 \\
\hline 24 & Lebanon & 3645 & 36 & 42.0 \\
\hline 25 & Malaysia & 306 & 4 & 58.4 \\
\hline 26 & Thailand & 50 & 0.8 & 56.6 \\
\hline 27 & Syria & 203 & 9 & 36.2 \\
\hline 28 & Sri Lanka & 152 & 0.6 & 48.3 \\
\hline 29 & Jordan & 345 & 3 & 51.5 \\
\hline 30 & Georgia & 642 & 5 & 31.8 \\
\hline 31 & Cyprus & 1269 & 18 & 62.7 \\
\hline 32 & Vietnam & 11 & 0.4 & 58.2 \\
\hline 33 & Taiwan & 21 & 0.3 & 72.3 \\
\hline 34 & Brunei & 331 & 7 & 50.4 \\
\hline 35 & Australia & 1046 & 32 & 63.0 \\
\hline 36 & Russia & 7358 & 129 & 43.7 \\
\hline 37 & New Zealand & 360 & 5 & 52.0 \\
\hline
\end{tabular}

reaction culminating in cytokine storm and lethal ARDS [19]. Animal models have demonstrated an increase in the mRNA and protein levels of ACE2 on vitamin D administration. This subsequently would lead to a decrease in oxygen saturation. Interestingly, Vitamin D upregulates ACE 2 expression and mitigate inflammatory responses by its anti-inflammatory properties. An increased prevalence of Vitamin D deficiency in many countries can lead to inefficient mitigation of inflammatory responses by increasing ACE 2, leading to increased mortality in COVID patients [12]. A cell culture study done on Vero E6 cell lines demonstrated that even after the entry of SARSCOV 2 into the cells, Vitamin D was able to have an inhibitory effect on the replication of the virus [20]. Animal model studies have attributed this inhibitory effect of vitamin D action on ACE 2 [21]. Aartjan J.et al. [22] showed that in cell culture, zinc inhibits RNA-dependent RNA polymerase. SARS- COV2 being an RNA virus, zinc can inhibit replication of these viruses. Vitamin D deficiency had been associated with a decrease in serum zinc levels. So vitamin D supplementation would be beneficial in such patients to normalize the serum zinc levels [23]. A 
Fig. 1 Scatterplot depicting COVID 19 cases per million and Vitamin D levels from different countries

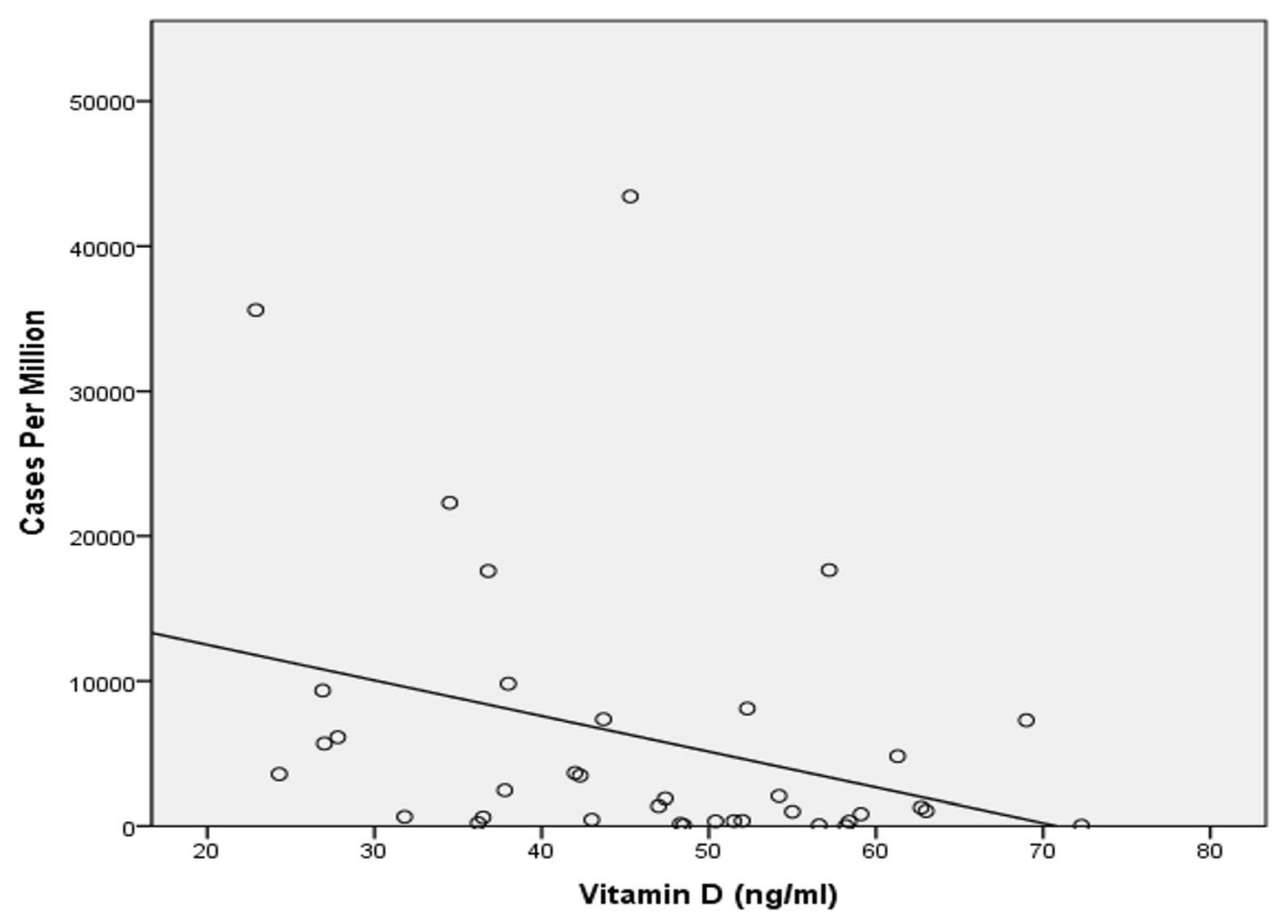

Fig. 2 Scatterplot depicting COVID 19 deaths per million and Vitamin D levels from different countries

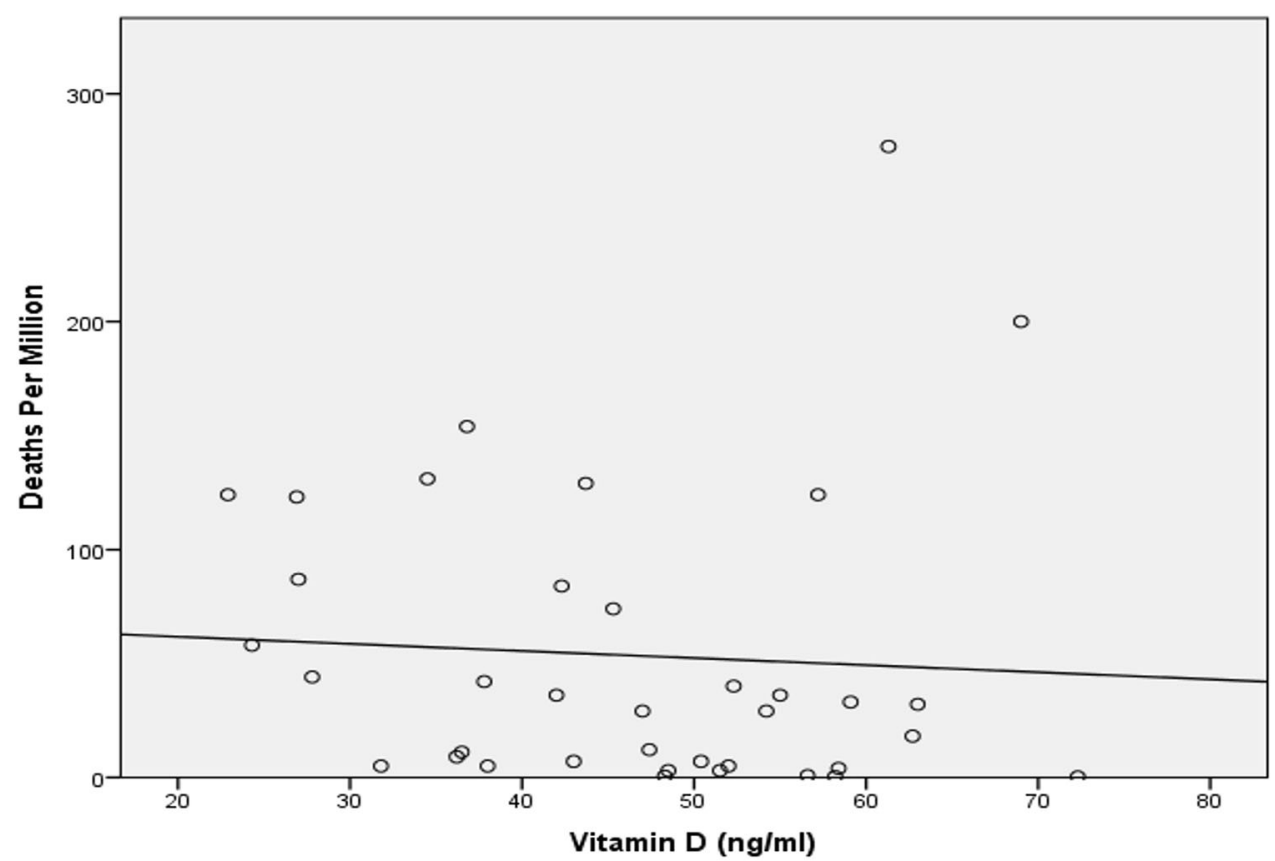

combination supplement of Vitamin D and zinc in COVID19 patients had shown a decreased incidence of cytokine storm by its immunomodulating activity [24].

Further, Vitamin D supplemented mice demonstrated milder symptoms of ARDS [25]. Vitamin D also reduces the generation of pro-inflammatory cytokines and increases the expression of anti-inflammatory cytokines, thereby mitigating the development of severe lung damages due to cytokine storm [26, 27]. Apart from the above-mentioned mechanisms, Vitamin D also contributes to the maintenance of the integrity of the physical barrier via E-cadherin [28].

A similar study was conducted by Ilie et al. (2020) for 20 European countries and concluded that the population with Vitamin D deficiency are most vulnerable for COVID19 [29]. Respiratory tract infections decreased as vitamin D concentration increased between $20-30 \mathrm{ng} / \mathrm{mL}$ [14]. To achieve these levels, 2000-5000 IU/d of vitamin D should 
be administered to all individuals with lower vitamin D levels [30]. Loading doses are required to achieve levels between 40-60 ng/mL. Also, vitamin D should be administered to all individuals with severe vitamin $\mathrm{D}$ deficiency to decrease the severity of COVID-19. Further, in the Asia-pacific region where people have adequate sunlight exposure, vitamin D deficient patients should be advised to have a healthy lifestyle with appropriate sun exposure in addition to the vitamin $\mathrm{D}$ rich diet. However, vitamin D supplementation should be administered with caution and should not be taken without a medical prescription to prevent hypervitaminosis D manifesting as fatigue, irritability, nausea, vomiting, dizziness, confusion and nervousness, hypercalcemia, and hypercalciuria [31].

Although, various potential mechanisms have been implicated in the possible use of Vitamin D in mitigating COVID-19 progression including regulation of RAS network, changes in the transcriptional activity of Vitamin D receptor, expression of antimicrobial peptides, and regulation of inflammatory response; clinical trials are required to substantiate the claims [32]. But, due to multiple confounders like dexamethasone in hospital-based treatment trials, the evidence for the effect of Vitamin D in COVID19 will have to be assessed by population-based trials indicating the prophylactic efficiency of Vitamin D [33]. The inverse correlation of Vitamin D and COVID-19 cases observed in our study also brings into focus the need to investigate other compounds that increase the VDR expression and have actions similar to Vitamin D. Quercetin is a nonsteroidal natural compound that activates VDR and its downstream pathways [34]. Similarly, Dexamethasone has been shown to increase VDR levels and accentuate downstream signaling [35]. The use of these drugs, alone or in combination with Vitamin D, has been hypothesized to be therapeutically beneficial in COVID-19 due to their immune-modulatory effect and regulation of expression of genes $[36,37]$. Further, the ability of vitamin $\mathrm{D}$ to supplement the immune modulatory action of Hydroxychloroquine is being explored in clinical trials [38, 39].

\section{Limitations}

The study hasn't considered other country-wise confounding factors that can lead to a difference in the number of COVID-19 cases in different countries. It also important to note that correlation does not prove causation, this just gives us an indication for a hypothesis. The role of vitamin D needs to be explored in COVID 19 through clinical trials.

\section{Conclusion}

The negative correlation observed between Vitamin D levels and the number of COVID-19 cases in the Asia Pacific region points to the possible protective effect of Vitamin D in blunting the infectivity of COVID-19 in causing debilitating infection in the countries in the Asia Pacific region. The multitude of factors that affects the COVID-19 infectivity and mortality calls for adequately designed population-based prospective studies to understand the prophylactic efficiency of Vitamin D and other analogs that modulate the VDR signaling. The emergence of evidence from such studies would help in defining policies regarding prophylactic supplementation of Vita$\min \mathrm{D}$.

Funding No funding was received for conducting this study.

\section{Compliance with Ethical Standards}

Conflict of interest The authors have no conflicts of interest to declare that are relevant to the content of this article.

Open Access This article is licensed under a Creative Commons Attribution 4.0 International License, which permits use, sharing, adaptation, distribution and reproduction in any medium or format, as long as you give appropriate credit to the original author(s) and the source, provide a link to the Creative Commons licence, and indicate if changes were made. The images or other third party material in this article are included in the article's Creative Commons licence, unless indicated otherwise in a credit line to the material. If material is not included in the article's Creative Commons licence and your intended use is not permitted by statutory regulation or exceeds the permitted use, you will need to obtain permission directly from the copyright holder. To view a copy of this licence, visit http://creativecommons. org/licenses/by/4.0/.

\section{References}

1. Holick MF. Sunlight and vitamin D for bone health and prevention of autoimmune diseases, cancers, and cardiovascular disease. Am J Clin Nutr. 2004;80(6 Suppl):1678S-S1688.

2. Rondanelli M, Miccono A, Lamburghini S, Avanzato I, Riva A, Allegrini P, et al. Self-care for common colds: the pivotal role of vitamin D, vitamin C, Zinc, and echinacea in three main immune interactive clusters (physical barriers, innate and adaptive immunity) involved during an episode of common colds-practical advice on dosages and on the time to take these nutrients/ botanicals in order to prevent or treat common colds. Evid Based Complement Alternat Med. 2018;2018:5813095.

3. Schwalfenberg GK. A review of the critical role of vitamin D in the functioning of the immune system and the clinical implications of vitamin D deficiency. Mol Nutr Food Res. 2011;55(1):96-108.

4. Kast JI, McFarlane AJ, Globinska A, Sokolowska M, Wawrzyniak P, Sanak M, et al. Respiratory syncytial virus infection influences tight junction integrity. Clin Exp Immunol. 2017;190:351-9. 
5. Chen Y, Leng K, Lu Y, Wen L, Qi Y, Gao W, et al. Epidemiological features and time-series analysis of influenza incidence in urban and rural areas of Shenyang, China, 2010-2018. Epidemiol Infect. 2020;148:e29.

6. Rossi GA, Fanous H, Colin AA. Viral strategies predisposing to respiratory bacterial superinfections. Pediatr Pulmonol. 2020. https://doi.org/10.1002/ppul.24699.

7. Pike JW, Christakos S. Biology and Mechanisms of Action of the Vitamin D Hormone. Endocrinol Metab Clin. 2017;46:815-43.

8. Liu PT, Stenger S, Li H, Wenzel L, Tan BH, Krutzik SR, et al. Toll-like receptor triggering of a vitamin D-mediated human antimicrobial response. Science. 2006;311:1770-3.

9. Adams JS, Ren S, Liu PT, Chun RF, Lagishetty V, Gombart AF, et al. Vitamin d-directed rheostatic regulation of monocyte antibacterial responses. J Immunol. 2009;182:4289-95.

10. Agier J, Efenberger M, Brzezinska-Blaszczyk E. Cathelicidin impact on inflammatory cells. Cent Eur $\mathrm{J}$ Immunol. 2015;40:225-35.

11. Barlow PG, Svoboda P, Mackellar A, Nash AA, York IA, Pohl J, et al. Antiviral activity and increased host defense against influenza infection elicited by the human cathelicidin LL-37. PLoS ONE. 2011;6:e25333.

12. Wong CK, Lam CWK, Wu AKL, Ip WK, Lee NLS, Chan IHS, et al. Plasma inflammatory cytokines and chemokines in severe acute respiratory syndrome. ClinExpImmunol. 2004;136:95-103.

13. Mahallawi WH, Khabour OF, Zhang Q, Makhdoum HM, Suliman BA. MERS-CoV infection in humans is associated with a pro-inflammatory Th1 and Th17 cytokine profile. Cytokine. 2018;104:8-13.

14. Martineau Adrian R, Jolliffe David A, Richard HL, et al. Vitamin D supplementation to prevent acute respiratory tract infections: systematic review and meta-analysis of individual participant data. BMJ. 2017;356:i6583.

15. Cannell JJ, Vieth R, Umhau JC, et al. Epidemic influenza and vitamin D. Epidemiol Infect. 2006;356:1129-40.

16. Xu J, Yang J, Chen J, et al. Vitamin D alleviates lipopolysaccharide-induced acute lung injury via regulation of the reninangiotensin system. Mol Med Rep. 2017;16:7432-8.

17. Hossein-nezhad A, Holick MF. Vitamin D for health: a global perspective. MayoClin Proc. 2013;88:720-55.

18. Yuan W, Pan W, Kong J, Zheng W, Szeto FL, Wong WE, et al. 1,25-dihy-droxyvitamin D3 suppresses renin gene transcription by blocking the activity of thecyclic AMP response element in the renin gene promoter. J Biol Chem. 2007;282:29821-30.

19. Ahn DG, Shin HJ, Kim MH, Lee S, Kim HS, Myoung J, et al. Current status of epidemiology, diagnosis, therapeutics, and vaccines for novel coronavirus disease 2019 (COVID-19). J Microbiol Biotechnol. 2020;30:313-24.

20. Mok CK, Ng YL, Ahidjo BA, et al. Calcitriol, the active form of vitamin $\mathrm{D}$, is a promising candidate for COVID-19 prophylaxis. MedRxiv 2020; published online June 22. Doi: https://doi.org/10. 1101/2020.06.21.162396 (preprint).

21. Xu J, Yang J, Chen J, Luo Q, Zhang Q, Zhang H. Vitamin D alleviates lipopolysaccharide induced acute lung injury via regulation of the rennin angiotensin system. Mol Med Rep. 2017;16:7432-8.

22. te Velthuis AJ, van den Worm SH, Sims AC, Baric RS, Snijder EJ, van Hemert MJ. $\mathrm{Zn}(2+)$ inhibits coronavirus and arterivirus RNA polymerase activity in vitro and zinc ionophores block the replication of these viruses in cell culture. PLoS Pathog. 2010;6(11):e1001176.

23. Shams B, Afshari E, Tajadini M, et al. The relationship of serum vitamin D and Zinc in a nationally representative sample of
Iranian children and adolescents: The CASPIAN-III study. Med J Islam Repub Iran. 2016;30:430.

24. Pal A, Squitti R, Picozza M, et al. Zinc and COVID-19: Basis of Current Clinical Trials. Biol Trace Elem Res. 2020. pp.1-11.

25. Yang H, Zhang J. Xu, Effect of Vitamin D on ACE2 and Vitamin $D$ receptorexpression in rats with LPS-induced acute lung injury. Chin J Emerg Med. 2016;25:1284-9.

26. Fabbri A, Infante M, Ricordi C. Editorial-Vitamin D status: a key modulator of innate immunity and natural defense from acute viral respiratory infections. Eur Rev Med Pharmacol Sci. 2020;25:4048-52.

27. Olson KC, Kulling Larkin PM, Signorelli R, Hamele CE, Olson TL, Conaway MR, et al. Vitamin D pathway activation selectively deactivates signaltransducer and activator of transcription (STAT) proteins and inflammatory cyto-kine production in natural killer leukemic large granular lymphocytes. Cytokine. 2018;111:551-62.

28. Grant WB, Lahore H, McDonnell SL, Baggerly CA, French CB, Aliano JL, et al. Evidence that vitamin D supplementation could reduce risk of influ-enza and COVID-19 infections and deaths. Nutrients. 2020;12:988.

29. Ilie P, Stefanescu S, Smith L. The role of vitamin D in the prevention of coronavirus disease 2019 infection and mortality. Aging Clin Exp Res. 2020;32(7):1195-8.

30. Heaney RP, Davies KM, Chen TC, Holick MF, Barger-Lux MJ. Human serum 25-hydroxycholecalciferol response to extended oral dosing with cholecalciferol. Am J Clin Nutr. 2003;77:204-10

31. Maji D. Vitamin D toxicity. Indian J Endocrinol Metab. 2012;16(2):295-6.

32. Hadizadeh F. Supplementation with vitamin D in the COVID-19 pandemic? [published online ahead of print, 2020 Jul 17]. Nutr Rev. 2020. https://doi.org/10.1093/nutrit/nuaa081.

33. Martineau AR, Forouhi NG. Vitamin D for COVID-19: a case to answer? Lancet Diabetes Endocrinol. 2020;8(9):735-6.

34. Lee KY, Choi HS, Choi HS, et al. Quercetin directly interacts with vitamin D receptor (VDR): structural implication of VDR activation by quercetin. Biomol Ther (Seoul). 2016;24(2):191-8.

35. Hidalgo AA, Deeb KK, Pike JW, Johnson CS, Trump DL. Dexamethasone enhances 1alpha, 25-dihydroxyvitamin D3 effects by increasing vitamin D receptor transcription. J Biol Chem. 2011;286(42):36228-37.

36. Glinsky GV. Tripartite combination of candidate pandemic mitigation agents: vitamin D, Quercetin, and Estradiol manifest properties of medicinal agents for targeted mitigation of the COVID-19 pandemic defined by genomics-guided tracing of SARS-CoV-2 targets in human cells. Biomedicines. 2020;8(5):129.

37. Pawar A, Pal A. Molecular and functional resemblance of dexamethasone and quercetin: A paradigm worth exploring in dexamethasone-nonresponsive COVID-19 patients [published online ahead of print, 2020 Sep 30]. Phytother Res. 2020. https://doi.org/ 10.1002/ptr.6886.

38. Pal A, Pawar A, Goswami K, Sharma P, Prasad R. Hydroxychloroquine and Covid-19: a cellular and molecular biology based update. Indian J Clin Biochem. 2020;35(3):274-84.

39. A Study of Hydroxychloroquine, Vitamin C, Vitamin D, and Zinc for the Prevention of COVID-19 Infection (HELPCOVID-19) NCT04335084.

Publisher's Note Springer Nature remains neutral with regard to jurisdictional claims in published maps and institutional affiliations. 